\title{
Ketosis and it is Economic Importance in Dairy Cattle: A Review
}

\author{
Getachew Tadesse* \\ College of Agriculture and Veterinary Medicine, Jimma University, Ethiopia
}

Submission: February 19, 2019; Published: March 22, 2019

*Corresponding author: Getachew Tadesse, College of Agriculture and Veterinary Medicine, Jimma, University, Ethiopia

\begin{abstract}
Ketosis is common metabolic disease that occurs during the last stage of pregnancy and early lactation of dairy cattle. It is caused by negative energy balance, which results impaired metabolism of carbohydrate and fatty acids that lead to excessive production of ketone bodies. The aims of this manuscript are to highlight ketosis with a special attention to management of the disease in dairy cattle and highlight economic importance of disease especially in subclinical ketosis. Ketosis occurs worldwide where dairy farms practiced with highest prevalence in early lactation. Risk factors for ketosis are body condition, season of calving and management of cow. Ketosis can be classified as primary and secondary based on the source of diseases. Primary ketosis is due to a lack of sufficient glucose to support the demand of milk production, where as secondary ketosis occur as a results of concurrent disease which may cause anorexia in cow. Based on clinical sign and ketone bodies concentrations ketosis can also divided into subclinical ketosis and clinical ketosis. Subclinical ketosis is increase ketone bodies above a threshold level in absence of obvious clinical signs. However clinical ketosis is characterized by increase ketone bodies as well as clinical signs such as anorexia, weight loss, licking and apparent blindness. Diagnosis of ketosis based on history and clinical observation and by measuring ketone bodies concentration. Differential diagnoses of ketosis are listeriosis, lead poisoning and rabies. Dextrose and oral propylene glycol used for treatments of ketosis. Ketosis is the most economic impact disease by reducing milk yield production, decreases reproductive performance and predisposes cows to different disease. Prevention and control of ketosis is proper transition cow nutrition and management. In Ethiopia, little work has been done on ketosis and literature on the epidemiology of ketosis has not been well documented and still insufficient. Therefore, further research should be conducted in order to evaluate the magnitude of the disease and its economy impact.
\end{abstract}

Keywords: Dairy Cattle; Economic Impact; Ketone Bodies; Ketosis

Lists of Abbreviations: BCS: Body condition score; BHBA: Beta hydroxybuteric acid; CoA: Coenzyme A; HSL: Hormone sensitive lipase; NAD+: Nicotinamide adenine dinucleotide oxidized; NADH: Nicotinamide adenine dinucleotide reduced; NEB: Negative energy balance; NEFA: Nonesterified fatty acids; SCK: Subclinical ketosis

\section{Introduction}

Ethiopia has the largest livestock population being the first in Africa countries and the 10th in the world and holds large potential for dairy development due to its large livestock population [1]. The transition period between late pregnancy and early lactation is certainly a stage with a high incidence of nutrition-mediated metabolic diseases such as ketosis and fatty liver in dairy cows. Postpartum dairy cows are often in a state of NEB that is induced by a low intake of dry matter and an increased demand for energy to support milk production [2]. Ketosis is an impaired metabolism of carbohydrate and volatile fatty acids that lead to excessive production of ketone bodies (betahydroxybutyrate, acetoacetate and acetone at 70\%, $28 \%$ and $2 \%$, respectively) [3]. Ketosis is a common metabolic disorder in high yielding dairy cows as result of NEB in early lactation, which can cause fat mobilization followed by elevations in ketone body concentrations in the body of dairy cattle [4].
There are lots of factors that can result in the development of ketosis in early lactation. Those are high body condition score and large fat mobilization around parturition increase the occurrence of ketosis in cows [5]. In many countries' ketosis can be common where intensive farming was practiced during winter-spring because lack supplement of pasture in dairy farms [6]. Ketosis can be clinical and sub-clinical based on clinical sign visibility in dairy cattle. Clinical ketosis has visible clinical symptoms such as anorexia, licking, blindness, hard dry feces, rapid loss of body condition, reduced milk production and etc. [7]. However, subclinical ketosis is an excess level of ketone bodies in the circulation without clinical signs [8]. Clinical ketosis is easy to diagnose by its clinical symptoms and several laboratory tests to measure ketone bodies in the blood, milk and urine [9]. But diagnosis subclinical ketosis only by measuring ketone body concentration. Minimum concentration of BHBA for $\mathrm{SCK}$ is $1.2 \mathrm{mmol} / \mathrm{L}$. BHBA is one of commonly circulating ketone 
body to diagnosis SCK. The upper threshold of concentration is $\geq 3.0 \mathrm{mmol} / \mathrm{L}$ in blood BHBA for SCK should be the onset of clinical signs [8].

The first treatment should be to increase feed intake by offering fresh or different feeds and Common treatment can be includes intravenous dextrose solutions, glucocorticoids, and oral propylene glycol and etc. [10]. Ketosis is a costly disease because negatively impacts on wellbeing, productivity and reproductive performance the cow [11]. Ketosis is risk factor for incidence of postpartum disorders (abomasal displacement and metritis) and culling, along with decreased milk yield and reproductive performance, which results in severe economic loss [12]. Ketosis can also in both case which means in clinical and subclinical form causes highly economic loss in dairy farmers because of loss of milk production and failure of affected animals to return to normal production after recovery [13]. Prevention of ketosis is management and nutrition transition cow. Which allow cows to develop a strong immune system, maintain normal concentrations of glucose in the blood, minimize the negative energy balance, prevent calving related diseases and develop a rumen adapted to the post-partum diet [14].

In fact, prevailing situation and presence of disease in worldwide, however ketosis is one of the diseases that have got less attention. But cause of very significant economic impact particularly sub clinical ketosis because silent profit loss in dairy cattle. In Ethiopia there is little information and also inadequate documented about ketosis.

Therefore, the objectives of this review are to:

1) Highlight ketosis with a special attention to management of the disease in dairy cattle.

2) Highlight economic importance of disease especially in subclinical ketosis.

\section{Litreature Reviews}

\section{Etiology}

Ketosis is a multifactorial disease caused by negative energy balance, resulting in fat cow syndrome in dairy cattle [15]. With a concurrent hypoglycemia, which results increase demands for glucose and insufficient propionate production during the early postpartum period in dairy cows [16]. Ketosis can be cause by the biochemical and hormonal as well as importance of predisposing factors for occurrence the diseases [17]. Ketosis is caused by impaired metabolism of carbohydrate and volatile fatty acids [13]. Starvation is one of common cause of ketosis due to a decreased consumption of feed (anorexia) and also lack feeding to cow during transition period [8]. Other uncommon cause of ketosis is poorly fermented silage due to the high content of butyrate. When cows consume the silage which contains high content butyrate the cow cannot metabolize the as fast as intake of butyrate. Because of this butyrate builds up in the rumen which cause is diffuses of butyrate across the rumen wall and enters the bloodstream. In liver butyrate is converted to BHBA results for occurrence of ketosis in dairy cattle [18].

\section{Epidemiology}

\section{Occurrence}

Ketosis is occurred as problem for the first time in 1920 to 1930 by Stinson the name called as acetomia or ketosis [17]. Ketosis occurs worldwide and common in ruminants because, a direct supply of glucose is essential for milk production use high amount glucose for the formation of lactose [13]. The incidence rate is the highest during the transition period of the cows with high intensity of prolonged morbidity [19]. And also, a high incidence of ketosis during lack pasture on many farms [20]. The following Figure 1 show that how much disease occurred in global. Source: [21].

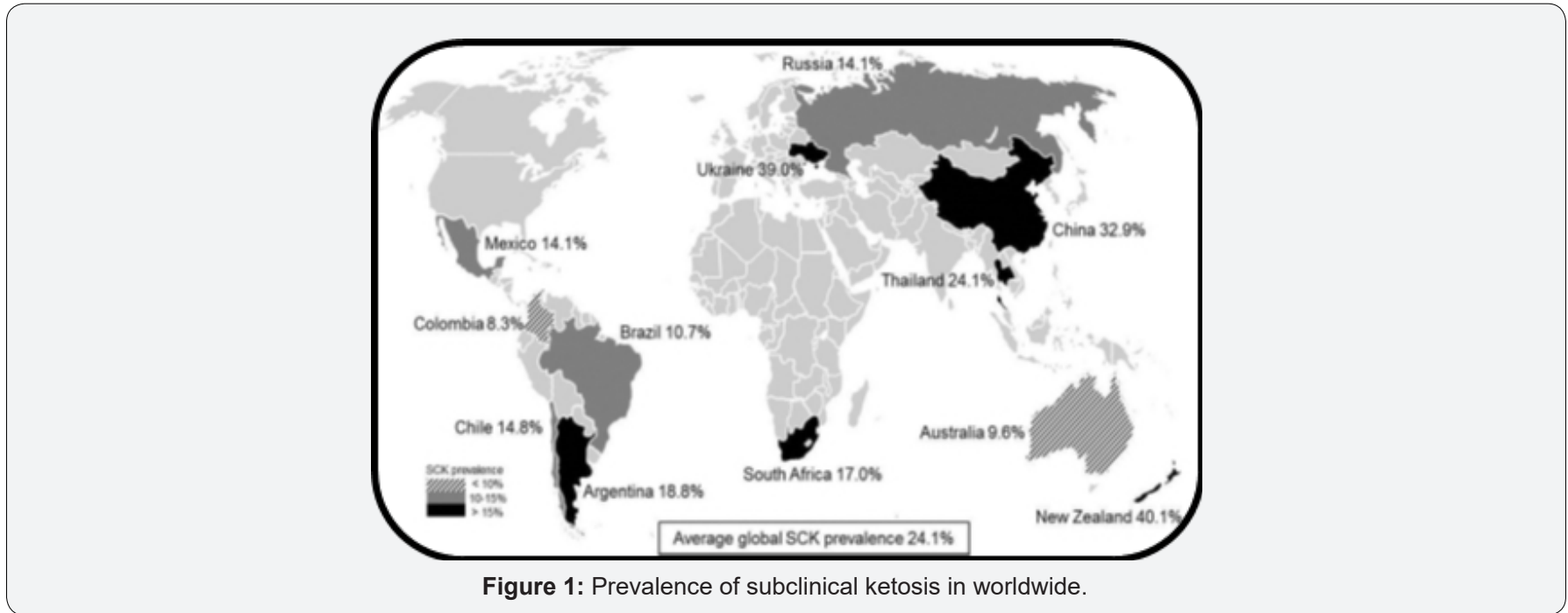

\section{Risk Factors for Development of Ketosis}

There are many risk factors of ketosis such as: presence of disease condition (any disease in the perpartum period that causes anorexia in cow) [22], breed, lactation, BCS at calving higher than 3.5 on a 5-point of scale [5], season of calving, and dry period length [23]. Other herd-level management factors 
(housing type, grouping strategies and pen moves) and many cow-level factors highly risk for ketosis [24] and also dry period length [25].

\section{Pathogenesis}

The period from three weeks before to three weeks after calving is considered the transition period [26]. During this period Negative energy balance and suboptimal mineral levels are common in cows [27]. Because of in early lactation of cow energy intake is insufficient to meet the energy output in milk [28]. Though there is insufficient ruminal production of propionic acid, the main precursor of glucose in ruminants, which results in hypoglycemia. Hypoglycemia leads to a mobilization of fat stores [29]. At the adipose tissue, activation of hormone sensitive lipase through the protein kinase A cascade results in phosphorylated HSL translocation to the lipid droplet and hydrolyzing triglycerides to NEFA and glycerol. In addition to HSL, phosphorylation of perilipin plays a key role in lipolysis during the transition to lactation period. Conversely, adipose triglyceride lipase, which is important in lipolysis in other species, is down regulated during the transition to lactation in dairy cows [30]. Once liberated, non-esterified fatty acids can be metabolized by many maternal and fetal tissues for energy production and fat synthesis [31].

Circulating NEFA is a significant contributor to milk fat synthesis in the mammary gland postpartum and can contribute to almost half of milk fat. During neutral or positive energy balance, when plasma NEFA is not elevated, NEFA contributes only minimally to milk fat synthesis [32]. NEFA are also largely metabolized by hepatic tissue. Uptake of NEFA from plasma by the liver is proportional to the plasma concentration and the rate of blood flow and is about $25 \%$ of NEFA passing through hepatic circulation [33]. NEFA and glycerol are oxidized to form AcetylcoA which converted into citrate then normal tricarboxylic acid cycle take place. However, production Acetyl-coA is greater than oxidation so that ketone bodies can be produced [29]. The below Figure 2 show mechanism of ketosis formation in dairy cows. Source: [29,34].

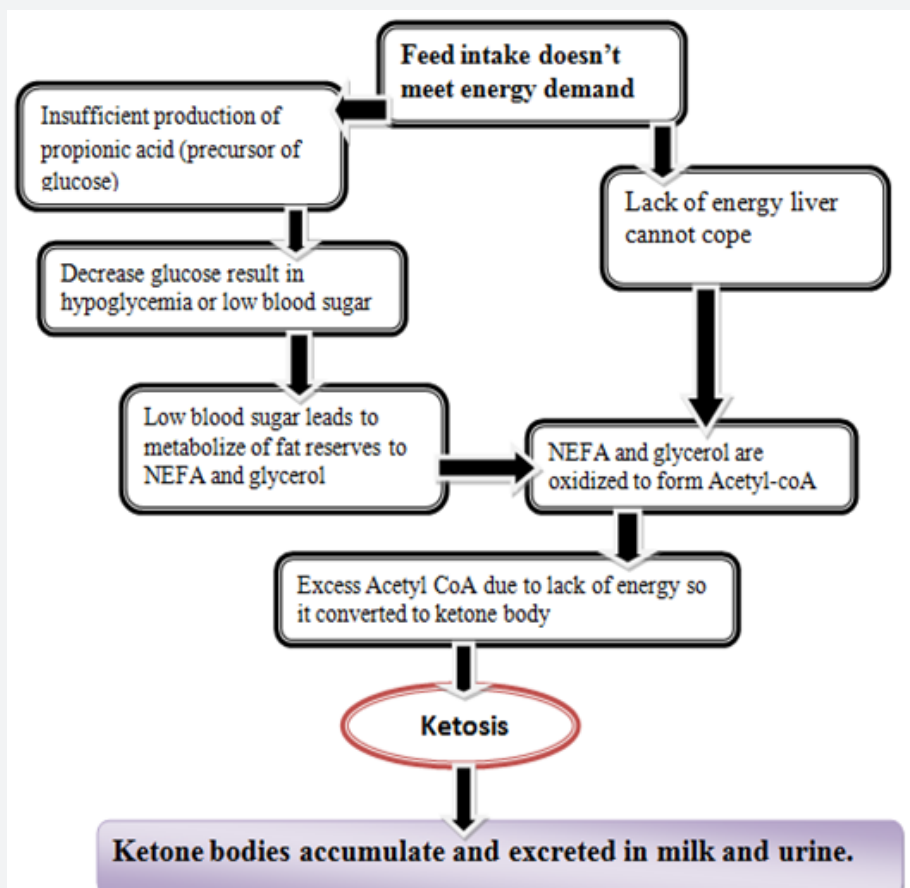

Figure 2: Showing how ketosis is caused when feed doesn't meet energy demand.

\section{Classification}

Ketosis can be classified as primary or secondary based on signs commenced and what concurrent diseases were facing the animal [34].

\section{Primary ketosis}

Primary ketosis is type of ketosis that occurred during sufficient glucose which use for milk production. When the cow underfeeding and negative energy balance there is sufficient of carbohydrate means lack of glucose as result of this primary ketosis occurred in transition period [35].

\section{Secondary ketosis}

A type of ketosis occurred as results of long period of anorexia and concurrent disease [35].

\section{Clinical finding}

Based on clinical signs and blood BHBA concentrations ketosis can be divided into clinical ketosis and subclinical ketosis [8].

\section{Clinical ketosis}

Clinical ketosis is characterized by an increase in blood, urine, 
or milk ketone bodies in conjunction with other visible signs typically occurs within the first six to eight weeks post-calving, resulting in anorexia, rapid loss of body weight, licking and blindness, hard dry feces, hypoglycemia, ketonemia, ketonuria, low level of hepatic glycogen, refused to take concentrate and decreased milk production [17]. Odor of ketone bodies in breath or milk of the cow is typical clinical sign [36]. Nervous signs are seen in primary ketosis [35].

\section{Subclinical ketosis}

Subclinical ketosis is defined as abnormally increase the concentrations of circulating ketone bodies without clinical signs in cow [37].

\section{Diagnosis}

The diagnosis of clinical and subclinical ketosis was confirmed with the help of different qualitative and quantitative tests. Clinical ketosis is diagnosed based on history and clinical observation which includes decreased appetite, weight loss, decreased milk production. However, due to most quite subjective clinical signs in the clinical ketosis and lack of signs or symptoms in subclinical ketosis. So, diagnosis of ketosis has been greatly enhanced by the availability several laboratories based rapid cow-side diagnostic tests [38]. These tests can be achieved by measuring ketone bodies concentration in the blood, urine and milk [20]. Gold standard laboratory diagnosis method includes; Fourier transform infrared (FTIR) spectrometry, Gas liquid chromatography, Nuclear magnetic resonance (NMR) spectroscopy and gas chromatography-mass spectrometry (GCMS) tests has been developed to measure BHBA, acetoacetate and acetone in the serum or plasma [38]. Quantitative laboratorybased determination of BHBA, acetoacetate and acetone require special laboratory equipment, ultraviolet spectrophotometer, biochemistry analyzer, centrifugation, blood sampling, freezing of plasma or serum samples, transport of frozen materials to the laboratory [38]. Therefore, to relieve inconveniences, to reduce laboratory costs and to provide results immediately after sampling cow-side diagnostic tests has been proven advantageous tests [8]. Several authors have used a cut-off point of $1.2 \mathrm{mmol} / \mathrm{L}$ $(1200 \mu \mathrm{mol} / \mathrm{L})$ concentration of BHBA to discriminate between healthy cows and cows affected by SCK [38].

The Precision Xtra meter is a useful cow side ketone test for the diagnosis of sub clinical ketosis in postpartum dairy cows. The Precision Xtra ketone monitoring system is a simple and a direct electrochemical test, which gives excellent results for measuring whole blood BHBA in cows. The ketone test strip contains the enzyme $\beta$ hydroxybutyrate dehydrogenase, which oxidizes BHBA to acetoacetate. This reduces nicotinamide adenine dinucleotide (NAD+) to NADH. The NADH is then reoxidized to NAD+ by an electron transfer mediator molecule. The electrical current generated by this conversion is measured by the meter and is directly proportional to the BHBA concentration. Cows with blood BHBA levels above $14.4 \mathrm{mg} / \mathrm{dl}$ are considered positive for ketosis [1]. Rothera's test results of urine and milk samples showed a color reaction varied from no color $(-)$, slightly purple $(+)$, moderately purple $(++)$, black-purple $(+++)$ and dark -purple $(++++)$ in the cases of ketosis. Rothera's test detects acetone and aceto-acetate but not beta-hydroxybutyric acid [39]. Measuring the ratio between the percentages of milk fat and milk protein is used to monitor the prevalence of SCK in herd. A ratio of fat to protein is higher than 1.5 indicates SCK where as a fat to protein ratio lower than 1.1 indicates suspected rumen acidosis. Moreover, sub clinically ketotic cows showed elevated level of folic acid and long-chain fatty acids in milk fat during the first nine weeks of lactation [38].

\section{Differential diagnosis}

Differential diagnoses for ketosis are listeriosis, lead poisoning and rabies. Those diseases associated with nervous signs including excessive licking, chewing and hyperesthesia, head pressing and apparent blindness [40].

\section{Treatment}

Cows may overcome ketosis without treatment. But it takes a prolong time to overcome the disease which results loss of cost because the cow up to overcome the disease decrease milk production. Therefore, immediate treatment is necessary [35]. The first treatment can be to increase feed intake to the cow and Common treatments for bovine ketosis can be intravenous dextrose solutions, glucocorticoids, and oral propylene glycol [10]. If a cow is largely or completely anorexic, treatment usually will begin with intravenous injection of glucose or possibly fructose. The effect of the administration of glucose is allows the reversal of ketogenesis and the establishments of normal patterns of energy metabolism [41]. Plasma concentrations of both glucose and insulin increase significantly about 48 hours after injection with dexamethasone [42]. The intravenous injections of $500 \mathrm{~mL}$ of $50 \%$ glucose solution results in transient hyperglycemia ( 2 to $2 \frac{1}{2} \mathrm{hr}$ ), increased insulin and decreased glucagon secretion and reduced plasma concentration of nonesterified fatty acids. Its effect has a marked improvement in most cows but relapses occur commonly unless repeated treatment is used [43].

\section{Economic Importance}

The most common economic problem in dairy farm is subclinical ketosis where intensive farming system practiced [44]. The disease runs sub-clinically; therefore, it might be called the silent profit robber on account of its impact on the profitability of dairy farm [44]. The disease goes unnoticed because of the absence of clinical signs, treatment is delayed while the performance of the animals is getting affected, hence causing heavy economic losses. Subclinical ketosis costs are estimated at $\$ 78$ per case; therefore, based on $40 \%$ prevalence in a 100 cow herd, the economic loss is approximately $\$ 3,120$ per year [45]. Ketosis is associated with increases in the incidence of postpartum disorders and culling, along with decreased milk yield and reproductive performance, resulting in severe economic loss [5]. Subclinical or 'hidden' ketotic cows were 
not only more likely to develop clinical ketosis, but also are at greater risk of developing clinical cases of other metabolic and reproductive disorders such as retained placenta, displaced abomasum and milk fever [46].

\section{Reduced Milk Yield}

High incidence of ketosis both in clinical and subclinical form causes economic loss to the dairy farmers due to loss of milk production as well as sharp drop of milk and failure of affected animals to return to normal production after recovery [13]. Early detection and treatment of SCK with propylene glycol $(300 \mathrm{ml}$ orally once daily until the ketosis resolved) improved milk production by about $1.5 \mathrm{lbs}$ of daily milk compared to cows whose SCK was left untreated [8]. The negative impacts of sub clinical ketosis on milk yield are very costly. In recent field study, cows with SCK produced 2.6lbs less daily milk (about $3.4 \%$ ) for the first 30 days after calving when compared to nonketotic cows. The severity of the milk yield loss due to SCK was associated with magnitude of the elevation in BHBA at the first diagnosis of SCK [6].

\section{Increased Risk for Displaced Abomasum}

Ketosis is widely accepted that decreased abomasum motility, followed by disturbed abomasal emptying and gas accumulation, are prerequisites for dilatation and subsequent displacement [47]. Herds with ketosis problems in early lactation cows also tend to have increased incidence of displaced abomasum greater than $8 \%$ [48]. The association of SCK with increased risk for displaced abomasums is common in dairy cattle. Recent study reported that blood $B H B A \geq 1.2 \mathrm{mmol} / \mathrm{L}$ in the first week after calving increased the risk for displaced abomasum [18].

\section{Impaired Fertility}

Associations between sub clinical ketosis and fertility have been inconsistent. Some researchers evaluated cows from mostly small and medium sized herds with ketosis (defined as blood $B H B A \geq 1.2 \mathrm{mmol} / \mathrm{L}$ ) in the first week after calving reduced the risk for pregnancy at first service. Early detection and treatment of SCK with oral propylene glycol increases first service conception [43].

\section{Control and prevention}

Transition cow management is critical in prevention of a range of metabolic diseases. The aims of the transition period are to allow cows to develop a strong immune system, maintain normal concentrations of calcium in the blood, minimize the negative energy balance, prevent calving related diseases and develop a rumen adapted to the post-partum diet [49]. Prevention of ketosis in the cow by proper nutrition, management of body condition and the use of certain feed additives, such as niacin, propylene glycol and ionophores [35]. Reducing the severity and NEB is crucial in the prevention of ketosis [50]. Ketosis prevention and control is the most important method in dairy industry for increasing milk yield products and dairy cows free from any disease. One of the guiding principles of sustainable livestock production is to feed high levels of roughage in the diet to promote good rumen digestion. For dairy cattle feed at least $60 \%$ fresh or conserved roughage, should have high quality during early lactation to meet the energy and protein requirements. This is especially important in the winter diet based on home-gown conserved forages and it may be difficult to supply sufficient energy if cows are high yielding [51]. During early lactation cows should not be too fat at calving, as this depresses their feed intakes. A body condition score of 2.5-3.0 on a 1-5 scale is optimal and anything higher is considered too fat and at greater risk of ketosis [52]. Concentrates feed during lactation should be introduced in small amounts, approximately two weeks before calving, to allow adjustments of the rumen micro flora and dietary changes during early lactation should be given gradually to reduce disease. Efforts should be made to ease the transition from gestation to lactation by offering highly palatable forage at calving, providing suitable accommodation and assistance where necessary [53].

\section{Status of Ketosis in Ethiopia}

In Ethiopia, little work has been done on ketosis in dairy cows, which comprise about $42 \%$ of the total cattle herds any disease related to production causes a heavy loss to the farmers [54]. Literature on the epidemiology of ketosis has not been well documented and still insufficient $[55,56]$. The occurrence of ketosis depends much on management, nutrition and climate [56]. The decrease in milk yield from ketosis affected cow ranged from 18.18 to $40 \%$ [56]. According to Mulat [56] the cows were administered with dextrose $50 \%$ plus dexamethasone effective restoration of milk-yield within 3-4 days. The highest prevalence of ketosis is recorded in the month of January [55,56]. This indicates that ketosis occurred mostly during the winter season when the animals are usually housed and there is scarcity of pasture [56]. The higher prevalence of ketosis occurs in higher age (8-9 years) groups during first month of lactation $[55,56]$. The prevalence rate of ketosis in and around Mekelle town (12.2\%) [55]. is higher than that of in and around Addis Ababa (11.2\%) [56] and Hawassa town of dairy farm (5.2\%) [57]. Summary of prevalence in the following Table1.

Source: [55-57] respectively.

Table 1: Prevalence of ketosis in some part of Ethiopia.

\begin{tabular}{|c|c|}
\hline Part of Ethiopia & Prevalence of ketosis \% \\
\hline Addis Ababa & 11.2 \\
\hline Hawassa & 5.2 \\
\hline Mekelle & 12.2 \\
\hline
\end{tabular}

\section{Conclusion and Recommendations}

Ketosis is metabolic disease that affects dairy cattle in transition period by increase ketone bodies. There are many risk factors and multifactorial etiology for occurrence ketosis. Ketosis can be classified into clinical and subclinical ketosis based on clinical finding. Clinical ketosis is increase concentration of ketone bodies with clinical sing, where as sub clinical ketosis only 
increase of ketone bodies concentration without clinical sing. It is major economic problem disease particularly subclinical ketosis because silent economy loss without observable clinical sings in cow. So that ketosis is major health concern of dairy farm in both developed and developing countries. Rothera's test is common diagnosis method in addition to history and clinical sign. Intravenous dextrose solution and oral propylene glycol are the most effective, inexpensive and easy treatment methods. Prevention and control of ketosis is critical by proper nutrition and good management of dairy cattle. There is inadequate information on the status of the disease in Ethiopia [58].

Depend on the above information mentioned in the review and conclusion remarks, the following recommendations are forwarded:

1. As much as possible implement good management practice (adequate bedding space, limit overcrowding and ensure proper feed delivery and adequate water access) in dairy cattle.

2. Cows should neither have been starved nor be over fat at calving.

3. The cow should be preventing from concurrent diseases.

4. Should give great attention for immediate diagnosis and proper treatment of affected cow to restore the milk yield and feed intake.

5. Creating awareness in order to minimize economic loss.

6. Further research should be conducted regarding to epidemiology and other associated items of ketosis in Ethiopia in order to evaluate the magnitude of the disease and its economy impact.

\section{References}

1. Tegegne A, Tadesse M, Yami A, Mekasha Y (2000) Market-oriented urban and peri-urban dairy systems. Urban Agriculture Magazine 1(2): 23-24.

2. Sordillo LM, Aitken SL (2009) Impact of oxidative stress on the health and immune function of dairy cattle. Vet Immunol Immunopathol 128(1-3): 104-109.

3. Ospina P, Stokol T, Overton TR (2010) Association between the proportions of sampled transition cows with increased non-esterified fatty acids beta-hydroxybutyrate disease incidence, pregnancy rate, milk production at the herd level. J Dairy Sci 93(8): 3595-3601.

4. Ingvartsen KL (2003) Prevention of feeding related disorders in dairy cattle. Report 54, Danish Institute of Agricultural Sciences pp. 227-293.

5. Busato A, Faissler D, Küpfer U, Blum JW (2002) Body condition scores in dairy cows: Associations with metabolic and endocrine changes in healthy dairy cows. J Vet Med Ser A 49(9): 455-460.

6. McArt J, Nydam D, Oetzel G (2012) A field trial on the effect of propylene glycol on displaced abomasum, removal from herd, reproduction in fresh cows diagnosed with subclinical ketosis. J Dairy Sci 95(5): 25052512.
7. Youssef M, El Khodery S, El deeb W, El Amaiem (2010) Ketosis: clinical findings the associated oxidative stress level. Trop Anim Health Prod 42(8): 1771-1777.

8. McArt J, Nydam D, Ospina PA, Oetzel GR (2011) A field trial on the effect of propylene glycol on milk yield and resolution of ketosis in fresh cows diagnosed with subclinical ketosis. J Dairy Sci 94(12): 6011-6020.

9. Cook N, Ward W, Dobson H (2001) Concentrations of ketones in milk in early lactation and reproductive performance of dairy cows. Vet Rec148(25): 769-772.

10. Gordon J, LeBlanc S, Neuder L, Herdt T, Kelton D, et al. (2012) Efficacy of combination butaphosphan cyanocobalamin product insulin for ketosis treatment. J Dairy Sci 95: 177.

11. Bobe G, Young JW, Beitz DC (2004) Invited review: Pathology, etiology, prevention, and treatment of fatty liver in dairy cows. J Dairy Sci 87(10): 3105-3124.

12. Shin EK, Jeong JK, Choi IS, Kang HG, Hur TY (2015) Relationships among ketosis, serum metabolites, body condition, and reproductive outcomes in dairy cows. Theriogenology 84(2): 252-60.

13. Radostists OM, Gay CC, Blood DC, Hinchdiff KW (2000) Veterinary Medicine: A Textbook of the Disease of Cattle, Horses, Sheep, Pigs and Goats. $9^{\text {th }}$ (Edn.) Saunders, London pp. 1452-1461.

14. Van Saun R (2016) Indicators of dairy cow transition risks: metabolic profiling revisited. Tierarztliche Praxis Grobtiere 44(2): 118-126.

15. Wang X (2012) Correlation between compositions of the bacterial community concentration of volatile fatty acids in the rumen during the transition period ketosis in dairy cows. Appl Environ Micriol 78(7): 2386-2392.

16. Dann H, Drackley J, Douglas GN, Janovick Guretzky N, Lither N (2005) Physiological and pathological adaptation in dairy cows that may increase susceptibility to periparturient diseases and disorders. Ital J Anim Sci 4: 323-344.

17. Zhang Z, Liu G, Wang H, Wang Z (2012) Detection of subclinical ketosis in dairy acows Pak J Vet 32(2): 156-160.

18. Duffield T, Lissemore K, McBride B, Leslie K (2009) Impact of hyperketonemia in early lactation dairy cows on health production. J Dair Sci 92(2): 571-580.

19. Radostits OM, Gay CC, Hinchcliff K, Constable PD (2010) Veterinary Medicine: A Textbook of the Diseases of Cattle, Horses, Sheep, Pigs and Goats. 10 ${ }^{\text {th }}$ (Edn.), Philadelphia, PA: Saunders Elsevier.1322-1346.

20. Duffield TF (2000) Subclinical ketosis in lactating dairy cattle. Vet Clin North Am Food Anim Pract 16(2): 231-253.

21. Nikolaus B, Stephan G, Jose R1, Rupert M. Bruckmaier and Josef J. G (2018). Prevalence of subclinical ketosis and production diseases in dairy cows in Central and South America, Africa, Asia, Australia and New Zealand, and Eastern Europe.

22. Calderon DF, Cook NB (2011) The effect of lameness on the resting behavior and metabolic status of dairy cattle during the transition period in a freestall housed dairy herd. J Dairy Sci 94(6): 2883-2894.

23. Watters RD, Guenther JN, Brickner AE, Rastani RR, Crump PM (2008) Effects of dry period length on milk production and health of dairy cattle. J Dairy Sci 91(7): 2595-2603.

24. McArt J, Nydam D and Oetzel G (2013) Dry period and parturient predictors of early lactation hyperketonemia in dairy cattle. J Dairy Sci 96(1): 198-209.

25. Santschi DE, Lefebvre DM, Cue RI, Girard CL, Pellerin D (2011) Incidence of metabolic disorders and reproductive performance following a short (35-d) or conventional (60-d) dry period management in commercial Holstein herds. J Dairy Sci 94(7): 3322-3330. 
26. Quiroz Rocha GF, LeBlanc S, Duffield T, Wood D, Leslie KE, et al. (2009) Evaluation of prepartum serum cholesterol and fatty acids concentrations as predictors of postpartum retention of the placenta in dairy cows. J Am Vet Med Asso 234(6): 790-793.

27. Goff JP (2006) Macromineral physiology and application to the feeding of the dairy cow for prevention of milk fever and other periparturient mineral disorders. Animal Feed Science and Technology 126(3-4): 237 257.

28. Reist M, Erdin D, von Euw D, Tschumperlin K, Leuenberger H (2003) Use of threshold serum milk ketone concentrations to identify risk for ketosis and endometritis in high yielding dairy cows. Am J Vet Res 64(2): 188-194.

29. Chapinal N, Carson M, Duffield T, Capel M, Godden S (2011) The association of serum metabolites with clinical disease during the transition period. J Dairy Sci 94(10): 4897-4903.

30. Koltes DA, Spurlock DM (2011) Coordination of lipid droplet-associated proteins during the transition period of Holstein dairy cows. J Dairy Sci 94(4): 1839-1848.

31. Adewuyi AA, Gruys E, Van Eerdenburg FJ (2005) None esterified fatty acids (NEFA) in dairy cattle. A review. Vet Q 27(3): 117-126.

32. Palmquist DL (2006) Milk Fat: Origin of fatty acids and influence of nutritional factors thereon. In Advanced Dairy Chemistry Volume 2 Lipids, McSweeney, Springer: New York, NY, USA. 43-92.

33. Reynolds CK, Aikman PC, Lupoli B, Humphries DJ, Beever DE (2003) Splanchnic metabolism of dairy cows during the transition from late gestation through early lactation. J Dairy Sci 86(4): 1201-1217.

34. Herdt TH (2000) Ruminant adaptation to negative energy balance. Vet Clin North Am Food Anim Pract 16 (2): 215-230.

35. Gordon J, LeBlanc S, Duffield T (2013) Ketosis treatment in lactating dairy cattle. Vet Clin N Am Food Anim Pract 29(2): 28-30.

36. LeBlanc SJ, Lissemore KD, Kelton DF, Duffield TF, Leslie KE (2005) Major Advances in Disease Prevention in Dairy Cattle. J. Dairy Sci. 89(4): 1267-1279.

37. Carrier J, Stewart S, Godden J, Fetrow, Rapnicki P (2004) Evaluation and use of three cow side tests for detection of subclinical ketosis in early postpartum cows. J Dairy Sci 87(11): 3725-3735.

38. Oetzel G (2004) Monitoring testing dairy herds for metabolic disease. Vet Clin North Am Food Anim Pract 20(3): 651-674.

39. Seifi H, LeBlanc S, Leslie K, Duffield T (2011) Metabolic predictors of post-partum disease culling risk in dairy cattle. Vet J188(2): 216-220.

40. Bradford PS (1990) Ketosis in ruminants. Text book of Large Animal Internal. Medicine $4^{\text {th }}(\mathrm{Edn})$, Louis, Toronto USA pp. 1364-1365.

41. Wagner S, Schimek D (2010) Evaluation of the effect of bolus administration of $50 \%$ dextrose solution on measures of electrolyte energy balance in postpartum dairy cows. Am J Vet Res 71(9): 1074-1080.

42. Jorritsma R, Thanasak J, Houweling M, Noordhuizen J, Müller K (2004) Effects of a single dose of dexamethasone-21-isonicotinate on the metabolism of heifers in early lactation. Vet Rec 155(17): 521-523.
43. Walsh R, Walton J, Kelton D, LeBlanc S, Leslie K, et al. (2007) The effect of subclinical ketosis in early lactation on reproductive performance of postpartum dairy cows. J Dairy Sci 90 (6): 2788-2796.

44. Denis Robichaud J, Des Côteaux L, Dubuc J (2011) Accuracy of a new milk strip cow side test for diagnosis of hyperketonemia. Bovine Practitioner $45: 97-100$.

45. Geishauser T, Leslie D, Kelton D, Duffield T (2001) Monitoring for subclinical ketosis in dairy herds. Compend Contin Educ Pract Vet 23: 6571.

46. Elanco (2015) Farm audit showed $30 \%$ of UK dairy cows had suclinical (hidden) ketosis. Vetclick/news.

47. Doll K, Sickinger M, Seeger T (2009) New aspects in the pathogenesis of abomasal displacement. Vet Journal 181(2): 90-96.

48. Duffield T and Bagg R. (2002). Herd level indicators for the prediction of high-risk dairy herds for subclinical ketosis. In Proc. Proc Am Assoc Bov Pract, Rome, GA. 175-176.

49. Melendez P, Risco C (2005) Management of transition cows to optimize reproductive efficiency in dairy herds. The Vet Clin of North Am. Food Anim Pract 21(2): 485-501.

50. Kocila P, Janzek D, Gracner T, Dobranic D, Duricic N (2013) Progesterone concentration and energy balance influence on Dairy cows with different milk yield during puerperium. Tierarztl Umschau 68: 266274.

51. Bystrom S, Jonsson S, Martinsson K (2002) Organic versus conventional dairy farming studies from the Öjebyn Project In Proc of the UK Organic Research 2002 Conference. Organic Centre Wales, Institute of Rural Studies, University of Wales Aberystwyth pp. 179-184.

52. Melendez P, Donovan G, Risco C, Goff J (2004) Plasma mineral energy metabolite concentrations in dairy cows fed an anionic prepartum diet that did or did not have retained fetal membranes after parturition. Ame J Vet Res 65(8): 1071-1076.

53. Moorby J, Dewhurst R, Evans R, Fishert W (2002) Effects of level of concentrate feeding during the second gestation of Holstein-Friesian dairy cows. 2. Nitrogen balance plasma metabolites. J Dairy Sci 85(1): 178-189.

54. Food Agriculture Organization (FAO) (1993) Cattle production. Rome, Italy. 47: pp. 255.

55. Gebrehiwot T, Dejene B, Bhoop S (2012) Prevalence and ClinicoPathology of Ketosis in Dairy Cows in Tigray Region of Ethiopia Br J Dairy Sci 4 (1): 115-120.

56. Mulat A, Gebrehiwot T, Gounder R, Nagappan R (2013) Prevalence Treatment of Ketosis in Dairy Cows in Around Addis Ababa, Ethiopia. British Journal of Dairy Sciences 3(3): 26-30

57. Fasil N, Juta TS (2016) Major Health Challenges of Dairy Cattle in Hawassa Town SNNPRS, Ethiopia. J Vet Sci Technol 7: 367.

58. Van Saun R (2016) Indicators of dairy cow transition risks: metabolic profiling revisited. Tierarztliche Praxis Grobtiere 44(2): 118-126. 
(CC This work is licensed under Creative CC) Commons Attribution 4.0 License

DOI: 10.19080/JDVS.2019.10.555800
Your next submission with Juniper Publishers will reach you the below assets

- Quality Editorial service

- Swift Peer Review

- Reprints availability

- E-prints Service

- Manuscript Podcast for convenient understanding

- Global attainment for your research

- Manuscript accessibility in different formats

( Pdf, E-pub, Full Text, Audio)

- Unceasing customer service

Track the below URL for one-step submission https://juniperpublishers.com/online-submission.php 